\title{
PENGARUH FASILITAS KERJA DAN DUKUNGAN ORGANISASI TERHADAP KEPUASAN KERJA PEGAWAI PADA DINAS LINGKUNGAN HIDUP KABUPATEN LABUHAN BATU UTARA
}

\author{
Raja Saul Marto Hendry \\ Manajemen, Fakultas Ekonomi \& Bisnis, Universitas Labuhanbatu \\ rajasaul365@gmail.com
}

\begin{abstract}
Abstrak
Penelitian ini bertujuan untuk menganalisis pengaruh Fasilitas Kerja Terhadap Kepuasan Kerja Pada Dinas Lingkungan Hidup Kabupaten Labuhanbatu Utara. Untuk menganalisis pengaruh Dukungan Organisasi terhadap Kepuasan Kerja Pada Dinas Lingkungan Hidup Kabupaten Labuhanbatu Utara. Untuk mengetahui pengaruh Fasilitas Kerja dan Dukungan Organisasi secara serempak terhadap Kepuasan kerja pada Dinas Lingkungan Hidup Kabupaten Labuhanbatu Utara. Subjek penelitian ini dilakukan pada Kantor Dinas Lingkungan Hidup Kabupaten Labuhanbatu Utara dengan populasi berjumlah 46 orang sehingga seluruh populasi tersebut merupakan sampel keseluruhan dengan teknik total sampling. Teknik pengumpulan data dilakukan dengan kuesioner atau data sekunder. Teknik analisis data menggunakan deskriptif statistik dan analisis regresi linier berganda. Hasil penelitian menunjukkan secara serempak variabel Fasilitas Kerja dan Dukungan Organisasi berpengaruh positif dan signifikan terhadap Kepuasan Kerja $F_{\text {hitung }} 13,668>F_{\text {tabel }} 3,21$ dan juga karena nilai signifikan $0,000<0,05$, secara parsial Fasilitas Kerja berpengaruh positif dan signifikan terhadap Kepuasan kerja diperoleh nilai $t_{\text {hitung }} 5,131>t_{\text {tabel }}$ 1,678 dan nilai probabilitas $t$ yakni $0,000<0,05$, secara parsial Dukungan Organisasi tidak berpengaruh positif dan signifikan terhadap Kepuasan kerja diperoleh nilai $\mathrm{t}_{\text {hitung }} 1,091<\mathrm{t}_{\text {tabel }} 1,678$ dan nilai probabilitas t yakni $0,281>0,05$.
\end{abstract}

Kata kunci : Fasilitas Kerja, Dukungan Organisasi, Kepuasan Kerja

\section{PENDAHULUAN}

Setiap orang yang bekerja mengharapkan memperoleh kepuasan dari tempatnya bekerja. Pada dasarnya kepuasan kerja merupakan hal yang bersifat individual karena setiap individu akan memiliki tingkat kepuasan yang berbeda-beda sesuai dengan nilainilai yang berlaku dalam diri setiap individu. Semakin banyak aspek dalam pekerjaan yang sesuai dengan keinginan individu, maka semakin tinggi tingkat kepuasan yang dirasakan. Kepuasan kerja adalah sikap umum terhadap pekerjaan seseorang yang menunjukkan perbedaan antara jumlah penghargaan yang diterima pekerja dan jumlah yang mereka yakini seharusnya mereka terima. Kepuasan kerja merupakan respon afektif atau emosional terhadap berbagai segi atau aspek pekerjaan seseorang sehingga kepuasan kerja bukan merupakan konsep tunggal. Seseorang dapat relatif puas dengan salah satu aspek pekerjaan dan tidak puas dengan satu atau lebih aspek lainnya. Kepuasan kerja merupakan 
sikap (positif) tenaga kerja terhadap pekerjaannya, yang timbul berdasarkan penilaian terhadap situasi kerja. Penilaian tersebut dapat dilakukan terhadap salah satu pekerjaannya, penilaian dilakukan sebagai rasa menghargai dalam mencapai salah satu nilai-nilai penting dalam pekerjaan.

Permasalahan tentang Kepuasan Kerja yang terjadi di UPT SDA Kualuh Barumun Sumber Daya Air, Cipta Karya dan Tata Ruang Provinsi Sumatera Utara adalah Kurang lancarnya komunikasi antar pegawai dengan pihak manajemen atau perusahaan. Dalam hal ini perlu adanya kesediaan pihak atasan untuk mendengar, memahami, dan mengakui pendapat ataupun prestasi pegawai agar terjadinya kepuasan kerja bagi tiap pegawai.

Fasilitas kerja merupakan faktor yang penting untuk memotivasi pegawai dalam meningkatkan kinerjanya dan sarana prasarana untuk membantu pegawai agar lebih mudah menyelesaikan pekerjaannya dan pegawai akan bekerja dengan lebih produktif. Dengan adanya fasilitas kerja, pegawai akan merasa nyaman dalam bekerja dan menimbulkan semangat kerja untuk mendapatkan hasil yang diharapkan oleh perusahaan. Memberikan fasilitas kerja yang memadai yang berarti pula menimbulkan perasaan betah bekerja pada pegawai sekaligus memberi penghormatan dan penghargaan kepada pegawai. Seorang pegawai akan merasa senang dan bahagia apabila pekerjaannya dihargai dengan sepadan. Permasalahan tentang Fasilitas Kerja yang terjadi di UPT SDA Kualuh Barumun Sumber Daya
Air, Cipta Karya dan Tata Ruang Provinsi Sumatera Utara adalah kurang tersedianya sarana dan prasarana yang mendukung seorang pegawai untuk melakukan pekerjaan yang bisa mendukung kepuasan kerja.

Dalam rangka pencapaian sasaran dan tujuan. Suatu lembaga organisasi perlu adanya suatu dukungan organisasi kepada pegawai. Dengan adanya suatu dukungan organisasi maka suatu lembaga perlu menyusun organisasinya dalam unit-unit kerja yang lebih kecil, dengan pembagian kerja,sistem kerja dan mekanisme kerja yang jelas. Semakin jelas penyusunan suatu organisasinya maka pegawai dapat bekerja secara efektif dan efisien dalam melaksanakan tugasnya. Dukungan organisasi merupakan penyediaan pengorganisasian, penyediaan sarana dan prasarana, pemilihan teknologi, kenyamanan lingkungan kerja serta kondisi dan syarat kerja. Permasalahan tentang Dukungan Organisasi yang terjadi di UPT SDA Kualuh Barumun Sumber Daya Air, Cipta Karya dan Tata Ruang Provinsi Sumatera Utara adalah kurang adanya pelatihan. Karena melalui pelatihan seorang pegawai dibekali untuk menjadi lebih terampil dan produktif.

\section{LANDASAN TEORI}

\subsection{Fasilitas Kerja}

Dalam suatu pencapaian tujuan perusahaan, diperlukan alat atau sarana pendukung yang digunakan dalam aktivitas sehari - hari di perusahaan tersebut, fasilitas yang digunakan bermacam-macam bentuk, jenis maupun manfaatnya, disesuaikan dengan dengan kebutuhan dan kemampuan 
perusahaan, kata fasilitas sendiri berasal dari bahasa Belanda "faciliteit" yang artinya prasarana atau wahana untuk melakukan atau mempermudah sesuatu. Fasilitas juga bisa dianggap suatu alat untuk mencapai tujuan perusahaan yang ada banyak faktor yang mendukung, salah satu diantaranya adalah fasilitas kerja karyawan merupakan faktor pendukung bagi kelancaran tugas yang mereka kerjakan, sehingga pekerjaan dapat dikerjakan sesuai dengan yang diharapkan. Fasilitas kerja terkait dengan lingkungan kerja, karena lingkungan kerja juga merupakan fasilitas kerja, dengan adanya lingkungan kerja yang nyaman maka karyawan dapat melaksanakan kerja dengan baik. Fasilitas kerja terkait dengan lingkungan kerja, karena lingkungan kerja juga merupakan fasilitas kerja, dengan adanya lingkungan kerja yang nyaman maka karyawan dapat melaksanakan kerja dengan baik.

$$
\text { Menurut Bary (2012:67) }
$$

fasilitas kerja adalah sebagai sarana yang diberikan perusahaan untuk mendukung jalannya nada perusahaan dalam mencapai tujuan yang ditetapkan oleh pemegang kendali.Menurut Tjiptono (2014 : 317) fasilitas merupakan sumber daya fisik yang harus ada sebelum suatu jasa ditawarkan kepada konsumen. Fasilitas merupakan sesuatu yang penting dalam usaha jasa, oleh karena itu fasilitas yang ada yaitu kondisi fasilitas, desain interior dan eksterior serta kebersihan harus dipertimbangkan terutama yang berkaitan erat dengan apa yang dirasakan konsumen secara langsung. Persepsi yang diperoleh dari interaksi pelanggan dengan fasilitas jasa berpengaruh terhadap kualitas jasa tersebut dimata konsumen.Sedangkan menurut Suryo Subroto (2010 :22)Fasilitas adalah segala sesuatu yang dapat mempermudah dan memperlancar pelaksanaan suatu usaha dapat berupa benda-benda maupun uang. Lebih luas lagi tentang pengertian Fasilitas dapat diartikan sebagai segala sesuatu yang dapatmemudahkan, memperlancar pelaksanaan suatu usaha.

\subsection{Dukungan Organisasi}

Shella Mary (2012:2)

mendeskripsikan, "perceived organizational support is an employee belief that the organization cares for and values his or her contribution to the success of the organization." Dukungan organisasi adalah kepercayaan pegawai bahwa organisasi peduli dan menilai setiap kontribusinya demi kesuksesan organisasi. Menurut Danish, Ramzan dan Ahmad (2013:313), "perceived organizational support is the expectations of employee that organization appraise their contribution and works for their welfare as well." Dukungan organisasi merupakan ekspektasi pegawai bahwa organisasi menghargai kontribusi dan pekerjaan yang pegawai lakukan dengan sebaiknya. Menurut Erdogan dan Enders (2012:8), "perceived organizational support refers to the degree to which an individual believes that the organization cares about him/her, values his/her input and provides his/her with help and support." Dukungan oganisasi merupakan derajat kepercayaan individu terhadap organisasi bahwa organisasi peduli kepadanya, menilai 
setiap masukan yang diberikan, dan menyediakan pertolongan dan bantuan untuknya. Allen et al. (2010:127) mendeskripsikan, "perceived organisational support is also defined as "how much the organisation values employees' contributions and cares about them." Dukungan organisasi didefiniskan sebagai seberapa banyak organisasi menilai kontribusi pegawai dan peduli terhadapnya. Dari beberapa uraian di atas, dapat disintesiskan bahwa dukungan organisasi adalah kepercayaan pegawai tentang seberapa jauh organisasi tempat dia bekerja menghargai kontribusi dan peduli akan kesejahteraannya.

\subsection{Kepuasan Kerja}

Dalam Robbins (2015: 170) disebutkan bahwa kepuasan kerja adalah suatu sikap umum terhadap pekerjaan seseorang sebagai perbedaan antara banyaknya ganjaran yang diterima pekerja dengan banyaknya ganjaran yang diyakini seharusnya diterima. Kepuasan kerja merupakan hal penting yang dimiliki individu di dalam bekerja. Setiap individu pekerja memiliki karakteristik yang berbeda - beda, maka tingkat kepuasan kerjanya pun berbeda beda pula tinggi rendahya kepuasan kerja tersebut dapat memberikan dampakyang tidak sama. Menurut Lawler (dalam Robbins, 2015:180), ukuran kepuasan sangat didasarkan atas kenyataan yang dihadapi dan diterima sebagai kompensasi usaha dan tenaga yang diberikan. Kepuasan kerja tergantung kesesuaian atau keseimbangan antara yang diharapkan dengan kenyataan. Priansa (2014:291) kepuasan kerja merupakan perasaan pegawai terhadap pekerjaannya, apakah senang / suka atau tidak senang / tidak suka sebagai hasil interaksi pegawai dengan lingkungan pekerjaannya atau sebagai presepsi sikap mental, juga sebagai hasil penilaian pegawai terhadap pekerjaannya. Perasaan pegawai terhadap pekerjaannya mencerminkan sikap dan perilakunya dalam bekerja.

Menurut Edy Sutrisno (2014:73) kepuasan keja menjadi masalah yang cukup menarik dan penting, karena terbukti besar manfaatnya bagi kepentingan individu, industri dan masyarakat. Bagi individu, penelitian tentang sebab-sebab dan sumbersumber kepuasan kerja memungkinkan timbulnya usahausaha peningkatan kebahagiaan hidup mereka. Bagi industri, penelitian mengenai kepuasan kerja dilakukan dalam rangka usaha peningkatan produksi dan pengaruh biaya melalui perbaikan sikap dan tingkah laku karyawannya. Selanjutnya, masyarakat tentu akan menikmati hasil kapasitas maksimum dari industri serta naiknya nilai manusia di dalam konteks pekerjaan. Ricahard, Robert dan Gordon (2012: 312) menegaskan bahwa kepuasan kerja berhubungan dengan perasaan atau sikap seseorang mengenai pekerjaan itu sendiri, gaji, kesempatan promosi atau pendidikan, pengawasan, rekan kerja, beban kerja dan lain-lain. Ia melanjutkan pernyataanya bahwa kepuasan kerja berhubungan dengan sikap seeorang mengenai kerja, dan ada beberapa alasan praktis yang membuat kepuasan kerja merupakan konsep yang penting bagi pemimpim. Penelitian menunjukkan 
pekerja yang puas lebih cenderung bertahan bekerja untuk organisasi. Pekerja yang puas juga cenderung terlibat dalam perilaku organisasi yang melampaui deskripsi tugas dan peran mereka, serta membantu mengurangi beban kerja dan tingkat stress anggota dalamorganisasi. Pekerja yang tidak puas cenderung bersikap menentang dalm hubungannya dengan kepemimpinan dan terlibat dalam berbagai perilaku yang kontraproduktif.

Wilson Bangun (2012 ; 327) menyatakan bahwa dengan kepuasan kerja seorang pegawai dapat merasakan pekerjaannya apakah menyenangkan atau tidak menyenangkan untuk dikerjakan.Bermacam-macam sikap seseorang terhadap pekerjaannya mencerminkan pengalaman yang menyenangkan dan tidak menyenangkan dalam pekerjaannya mencerminkan pengalamannya serta harapan-harapan terhadap pengalaman masa depan. Pekerjaan itu memberi kepuasan bagi pemangkunya. Kejadian sebaliknya, ketidakpuasan akan diperoleh bila suatu pekerjaan tidak menyengkan untuk dikerjakan.

Kepuasan kerja menurut Dadang (2013:15) adalah keadaan emosional yang menyenangkan atau tidak menyenangkan terhadap pekerjaan, kepuasan kerja mencerminkan perasaan seeorang terhadap terhadap pekerjaannya. Edy Sutrisno (2014 : 75), mengemukakan kepuasan kerja adalah keadaan emosional yang menyenangkan atau tidak menyenangkan bagi para karyawan memandang pekerjaan mereka. Kepuasan kerja mencerminkan perasaan seeorang terhadap terhadap pekerjaannya. Menurut Siagian (2013 : 295) kepuasan kerja merupakan suatu cara pandang seseorang baik yang positif maupun negatif tentang pekerjaannya.

Menurut Mangkunegara (2011: 117), kepuasan kerja adalah suatu perasaan yang menyokong atau tidak menyokong diri pegawai yang berhubungan dengan pekerjaannya maupun dengan kondisi dirinya. Selanjutnya menurut Handoko (2011: 193), kepuasan kerja adalah keadaan emosional yang menyenangkan atau tidak menyenangkan dengan mana para karyawan memandang pekerjaan mereka. Kepuasan kerja mencerminkan perasaan seseorang terhadap pekerjaannya.

\subsection{Kerangka Konseptual}

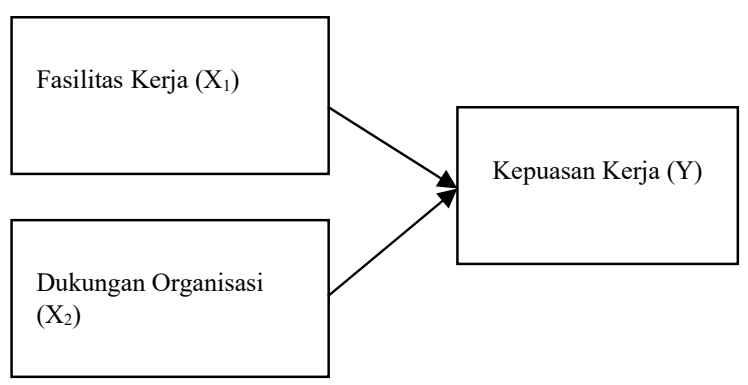

\section{Gambar 2.1 Kerangka Konseptual}

\section{METODE PENELITIAN}

\subsection{Metode Analisis Regresi}

\section{Linier Berganda}

Menurut Sugiyono (2013:210) menyatakan bahwa " analisis regresiberganda merupakan suatu alat analisis yang digunakan untuk memprediksikanberubahnya nilai variable tertentu bila variable lain berubah". Jumlah variabelindependen yang diteliti lebih dari satu, sehingga dikatakan regresi berganda. Hubungan antara 
variable tersebut dapat dicirikan melalui model matematika yangdisebut dengan model regresi. Model regresi berganda dilakukan untuk mengetahuiapakah ada pengaruh yang signifikan dari variable yang diteliti. Analisis regresilinier berganda dalam penelitian ini dilakukan untuk mengetahui apakah adapengaruh yang signifikan dari variable yang diteliti..Untuk memperoleh hasil analisis data, peneliti menggunakan bantuan paket program statistik SPSS (Statistikal Package for the Social Scient). Model persamaannya dapat digambarkan sebagai berikut:

$$
\mathbf{Y}=\mathbf{a}+\mathbf{b}_{1} \mathbf{X}_{1}+\mathbf{b}_{2} \mathbf{X}_{2}+\mathbf{e}
$$

Keterangan:

\begin{tabular}{|c|c|c|}
\hline $\mathrm{Y}$ & $=$ & Kepuasan \\
\hline Kerja & & \\
\hline $\mathrm{a}$ & & onstanta \\
\hline $\mathrm{X}_{1}$ & $=$ & Fasilitas \\
\hline Kerja & & \\
\hline $\mathrm{X}_{2}$ & $=$ & Dukungan \\
\hline Organisasi & & \\
\hline$b_{1 \ldots 2}$ & $=$ & Koefisien \\
\hline Regresi & & \\
\hline $\mathrm{e}$ & $=$ & Standar \\
\hline
\end{tabular}

Error

Jenis kriteria ketepatan, yaitu:

A . Uji Serempak (Uji F)

Uji serempak (Uji F) bertujuan untuk mengetahui besarnya pengaruh masing-masing variabel independen secara individual (parsial) terhadap variabel dependen.

\section{B . Uji Parsial (Uji T)}

Uji parsial bertujuan untuk mengetahui pengaruh bersama-sama variabel independen (X) terhadap variabel dependen (Y).Uji $\mathrm{T}$ yaitu suatu uji untuk mengetahui signifikasi dari pengaruh variabel independen terhadap variabel dependen secara individual dan menganggap dependen yang lain konstan. Signifikansi pengaruh tersebut dapat diestimasi dengan membandingkan antara nilai $t_{\text {tabel }}$ dengan nilai $t_{\text {hitung. Apabila nilai }}$ $t_{\text {hitung }}>t_{\text {tabel }}$ maka variabel independen secara individual mempengaruhi variabel dependen, sebaliknya jika nilai $t_{\text {hitung }}<t_{\text {tabel }}$ maka variabel independen secara individual tidak mempengaruhi variabel dependen (J. Supranto, 2009: 336).

\section{C . Koefisien Determinan $\left(\mathbf{R}^{2}\right)$}

Koefisien determinasi adalah salah satu nilai statistik yang dapat digunakan untuk mengetahui besar pengaruh antara dua variabel. Nilai koefisien determinasi yang biasanya diberi simbol $\mathrm{R}^{2}$ menunjukkan besar pengaruh variabel independen dan variabel dependen dari hasil nilai $\mathrm{R}^{2}$ x 100\%. (J. Supranto, 2009: 336). Identifikasi determinan $\left(\mathrm{R}^{2}\right)$ digunakan untuk melihat seberapa besar pengaruh variabel-variabel indipenden terhadap variabel dependen. Dalam output SPSS koefisien determinasi terletak pada tabel Model summarydan tertulis $\mathrm{R}$ Square. Namun untuk regresi linear berganda sebaiknya menggunakan Adjusted $R \quad$ Square, karena disesuaikan dengan jumlah variabel independen yang digunakan dalam penelitian. Nilai $\mathrm{R}$ square dikatakan baik jika diatas 0,5 karena nilai $\mathrm{R}$ Square berkisar antara 0 sampai 1 (Sugiyono, 2012 : 61). 


\section{HASIL PENELITIAN DAN PEMBAHASAN}

\subsection{Hasil Penelitian}

1.Hasil Analisis Regresi Linier

Berganda (Uji F, Uji T, dan

Koefisien Determinan)

a. Hasil Analisis Regresi Linier

Berganda

Hasil Persamaan Analisis Regresi Linier Berganda bertujuan untuk mengetahui pengaruh dari variabelvariabel independen terhadap variabel dependen,

$$
\mathbf{Y}=5,546+0,575 \mathbf{X}_{1}+0,080 \mathbf{X}_{2}+\mathbf{e}
$$

\section{Keterangan :}

1. Koefisien regresi konstanta sebesar 5,546 mempunyai arti jika ada atau variabel Fasilitas (X1) dan Dukungan Organisasi (X2), maka Kepuasan kerja(Y) pegawai akan sebesar 5,546.

2. Koefisien regresi Fasilitas Kerja (X1) sebesar 0,575 mempunyai arti bahwa setiap terjadi penambahan Fasilitas Kerja (X1) sebesar 0,575 maka Kepuasan Kerja (Y) Pegawai sebesar 1 kali.

3. Koefisien regresi Dukungan Organisasi (X2) sebesar 0,080 mempunyai arti bahwa setiap terjadi penambahan Dukungan Organisasi (X2) sebesar 0,080 maka Kepuasan Kerja (Y) Pegawai sebesar 1 kali.

\section{a. Uji T}

Uji parsial (Uji T) dilakukan untuk menguji secara parsial (individu) apakah Fasilitas Kerja (X1) dan Dukungan Organisasi (X2) berpengaruh terhadap Kepuasan Kerja (Y) dapat dilihat pada tabel 4.10 berikut:

a. Variabel Fasilitas Kerja $\left(\mathrm{X}_{1}\right)$,

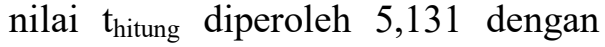
taraf signifikan 0,000 . Dengan demikian nilai $t_{\text {hitung }}(5,131)>t_{\text {tabel }}$ $(2,016)$ dengan taraf signifikan
$0,000<0,05$. Artinya bahwa secara parsial Fasilitas Kerja $\left(\mathrm{X}_{1}\right)$ berpengaruh positif dan signifikan terhadap Kepuasan kerja (Y) pada UPT SDA Kualuh Barumun Sumber Daya Air, Cipta Karya dan Tata Ruang Provinsi Sumatera Utara. Dengan demikian hipotesis dapat diterima.

b. Variabel Dukungan Organisasi $\left(\mathrm{X}_{2}\right)$, nilai $\mathrm{t}_{\text {hitung }}$ diperoleh 1,091 dengan taraf signifikan 0,281. Dengan demikian nilai $t_{\text {hitung }}(1,091)$ $<t_{\text {tabel }}(2,016)$ dengan taraf signifikan $0,281>0,05$. Artinya bahwa secara parsial Dukungan Organisasi $\left(\mathrm{X}_{2}\right)$ tidak berpengaruh positif dan signifikan terhadap kepuasan kerja (Y) pada UPT SDA Kualuh Barumun Sumber Daya Air, Cipta Karya dan Tata Ruang Provinsi Sumatera Utara. Dengan demikian hipotesis dapat ditolak.

b. Uji F

Uji $F$ adalah pengujian variabel independen secara bersama yang dilakukan untuk melihat signifikansi dari pengaruh variabel independen secara bersama-sama terhadap variabel dependen pengujian satu sisi dan menggunakan hipotesis sebagai berikut :

- $\quad$ Ho : b1 $=\mathrm{b} 2=0$ berarti tidak ada pengaruh yang signifikan antara variabel independen (Fasilitas Kerja dan Dukungan Organisasi) terhadap variabel dependen (Kepuasan kerja).

- $\quad$ Ho : b1 $\neq$ b2 $\neq 0$ berarti ada pengaruh yang signifikan antara variabel independen (Fasilitas Kerja dan Dukungan Organisasi) terhadap variabel dependen (Kepuasan kerja). Dengan kriteria pengujian sebagai berikut :

- Ho ditolak jika $F_{\text {hitung }}<F_{\text {tabel }}$

- $\quad$ Ho diterima jika $F_{\text {hitung }}>F_{\text {tabel }}$ 
Dengan menggunakan tingkat keyakinan sebesar $95 \%$ atau 0,05 dan derajat kebebasan $(\mathrm{df})=(\mathrm{n}-\mathrm{k}) ;(\mathrm{k}-$ 1) $=(44) ;(2)$ dimana $n$ adalah jumlah responden dan $\mathrm{k}$ adalah jumlah variabel, maka diketahui bahwa $\mathrm{F}_{\text {tabel }}=3,21$.

Dari hasil perhitungan uji statistik yang dilakukan maka diperolah nilai $\mathrm{F}_{\text {hitung }}$ sebesar 13,668 dengan taraf signifikan 0,000. Dengan demikian, nilai $F_{\text {hitung }}(13,668)>F_{\text {tabel }}(3,21)$ dengan taraf signifikan $0,000<0,05$. Artinya bahwa Fasilitas Kerja $\left(\mathrm{X}_{1}\right)$ dan Dukungan Organisasi $\left(\mathrm{X}_{2}\right)$ secara simultan (bersama-sama) berpengaruh positif dan signifikan terhadap Kepuasan kerja (Y) pada UPT SDA Kualuh Barumun Sumber Daya Air, Cipta Karya dan Tata Ruang Provinsi Sumatera Utara. Dengan demikian hipotesis dapat diterima.

\section{c. Koefisien Determinan $\left(\mathbf{R}^{\mathbf{2}}\right)$}

Untuk mengetahui seberapa besar pengaruh Fasilitas Kerja $\left(\mathrm{X}_{1}\right)$ dan Dukungan Organisasi $\left(\mathrm{X}_{2}\right)$ terhadap Kepuasan kerja (Y) baik secara simultan maka akan dilakukan pengujian terhadap persamaan garis regresi tersebut melalui hipotesis penelitian. Pengaruh Fasilitas Kerja $\left(\mathrm{X}_{1}\right)$ dan Dukungan Organisasi $\left(\mathrm{X}_{2}\right)$ terhadap Kepuasan kerja (Y) secara simultan ditunjukkan oleh koefisien determinasi $\left(\mathrm{R}^{2}\right)$ dari analisis regresi. Koefisien determinasi $\left(\mathrm{R}^{2}\right)$ ini menunjukkan proposi atau persentase variasi total variabel dependent $(\mathrm{Y})$ yang dijelaskan oleh independen $\mathrm{X}_{1}$ dan $\mathrm{X}_{2}$ secara bersama-sama. Hasil estimasi dengan menggunakan SPSS versi 22.00 for windows didapat hasil sebagai berikut :
Berdasarkan tabel 4.13 hasil pengujian koefisien determinasi dapat diketahui antara lain nilai $R$ dan $R$ Square sebagai berikut :

1. Nilai $R$ sebesar 0,623 sama dengan $62.3 \%$ yang menunjukkan bahwa hubungan antara variabel Fasilitas Kerja (X1) dan Dukungan Organisasi (X2) terhadap Kepuasan Kerja (Y) cukup erat.

2. Besarnya nilai koefisien determinan 0,389 atau sama dengan $38,9 \%$. Nilai tersebut berarti bahwa sebesar 38,9\% menegaskan bahwa Kepuasan Kerja (Y) pegawai dapat dijelaskan melalui variabel Fasilitas Kerja (X1) dan Dukungan Organisasi (X2).

3. Besarnya nilai koefisien Adjusted R.Square 0,360 atau sama $36 \%$. Nilai tersebut berarti bahwa sebesar 36\% menegaskan bahwa Kepuasan Kerja (Y) pegawai dapat dijelaskan melalui variabel Fasilitas Kerja (X1) dan Dukungan Organisasi (X2).

\section{A. Pembahasan}

Berdasarkan R square sebesar 0,389 berarti 38,9\% variasi perubahan dari Kepuasan kerja (Y) disebabkan oleh faktor Fasilitas Kerja $\left(\mathrm{X}_{1}\right)$ dan Dukungan Organisasi $\left(\mathrm{X}_{2}\right)$. Sedangkan sisanya $61,1 \%$ variasi atau Kepuasan kerja disebabkan oleh variabel-variabel lain yang tidak disertakan dalam penelitian ini. Berdasarkan hasil uji $\mathrm{F}$ diketahui nilai $F_{\text {hitung }}(13,668)>F_{\text {tabel }}(3,21)$ dengan tingkat signifikansi sebesar $0,000<0,05$ atau $5 \%$. Hal tersebut menunjukkan bahwa variabel Fasilitas Kerja $\left(\mathrm{X}_{1}\right)$ dan Dukungan Organisasi $\left(\mathrm{X}_{2}\right)$ secara simultan mempunyai pengaruh yang signifikan terhadap kepuasan kerja 
(Y). Sehingga hipotesis yang menyatakan "Fasilitas Kerja dan Dukungan Organisasi berpengaruh secara simultan terhadap Kepuasan kerja pada UPT SDA Kualuh Barumun Sumber Daya Air, Cipta Karya dan Tata Ruang Provinsi Sumatera Utara" dapat dibuktikan.

Berdasarkan hasil uji $t$ variabel Fasilitas Kerja $\left(\mathrm{X}_{1}\right)$ dengan nilai $t_{\text {hitung }}(5,131)>t_{\text {tabel }}(1,678)$ dengan taraf signifikan $0,000<0,05$. Dan variabel Dukungan Organisasi $\left(\mathrm{X}_{2}\right)$ dengan nilai $t_{\text {hitung }}(1,091)<t_{\text {tabel }}$ $(1,678)$ dengan taraf signifikan $0,281>0,05$.

Hal tersebut menunjukkan bahwa variabel Fasiltas Kerja berpengaruh positif dan signifikan terhadap Kepuasan kerja pada UPT SDA Kualuh Barumun Sumber Daya Air, Cipta Karya dan Tata Ruang Provinsi Sumatera Utara. Dengan demikian hipotesis dapat diterima. Serta secara parsial Dukungan Organisasi tidak berpengaruh positif dan signifikan terhadap kepuasan kerja pada UPT SDA Kualuh Barumun Sumber Daya Air, Cipta Karya dan Tata Ruang Provinsi Sumatera Utara. Dengan demikian hipotesis dapat ditolak.

\section{KESIMPULAN DAN SARAN}

\subsection{Kesimpulan}

Setelah melakukan penelitian dan melihat hasil-hasil dari penelitian tersebut, maka dapat disimpulkan sebagai berikut :

Ada pengaruh positif dan signifikan antara variabel Fasilitas Kerja $\left(\mathrm{X}_{1}\right)$ terhadap Kepuasan kerja (Y) pada UPT SDA Kualuh Barumun Sumber Daya Air, Cipta Karya dan Tata Ruang Provinsi Sumatera Utara, ditinjau dari pengujian secara parsial diperoleh nilai $t_{\text {hitung }} 5,131$ lebih besar dari pada $t_{\text {tabel }} 2,016$ dan juga karena nilai signifikan t yakni 0,000 lebih kecil dari 0,05.

1.

idak Ada pengaruh positif dan signifikan antara variabel Dukungan Organisasi $\left(\mathrm{X}_{2}\right)$ terhadap Kepuasan kerja (Y) pada UPT SDA Kualuh Barumun Sumber Daya Air, Cipta Karya dan Tata Ruang Provinsi Sumatera Utara, ditinjau dari pengujian secara parsial diperoleh nilai $t_{\text {hitung }} 1,091$ lebih kecil dari pada $t_{\text {tabel }}$ 2,016 dan juga karena nilai signifikan t yakni 0,281 lebih besar dari 0,05 .

2. Ada pengaruh positif dan signifikan antara variabel Fasilitas Kerja dan Dukungan Organisasi terhadap Kepuasan kerja kerja pada UPT SDA Kualuh Barumun Sumber Daya Air, Cipta Karya dan Tata Ruang Provinsi Sumatera Utara, ditinjau dari pengujian secara simultan nilai $\mathrm{F}_{\text {hitung }} 13,668$ lebih besar dari $F_{\text {tabel }}$ 3,21 dan juga karena nilai signifikan 0,000 lebih kecil dari 0,05 .

\subsection{Saran}

Berdasarkan hasil analisis dan kesimpulan penelitian, maka diajukan beberapa saran sebagai berikut :

1. Berdasarkan hasil observasi mengenai Fasilitas Kerja $\left(\mathrm{X}_{1}\right)$ yang cukup pada hampir semua indikator Fasilitas Kerja $\left(\mathrm{X}_{1}\right)$ namun peneliti menyarankan untuk agar UPT SDA Kualuh Barumun Sumber Daya Air, Cipta Karya dan Tata Ruang Provinsi Sumatera Utara, bisa memfasilitasi pegawai dengan sarana dan prasarana yang mendukung seorang pegawai 
untuk melakukan pekerjaan yang bisa mendukung kepuasan kerja.

2. Perlu dilakukan peningkatan Dukungan Organisasi $\left(\mathrm{X}_{2}\right)$ oleh UPT SDA Kualuh Barumun Sumber Daya Air, Cipta Karya dan Tata Ruang Provinsi Sumatera Utara, terutama tentang pelatihan agar pegawai bisa menjadi lebih terampil dan produktif. 3. Perlu dilakukan memperhatikan Kepuasan kerja (Y) pada setiap karyawan agar hasil lebih memuaskan sesuai dengan tujuan visi misi yang dijalankan di UPT SDA Kualuh Barumun Sumber Daya Air, Cipta Karya dan Tata Ruang Provinsi Sumatera Utara

\section{DAFTAR PUSTAKA}

[1] Allen et al. 2010. Organizational commitmen: Evidence of career stage effects. Journal of Business Research,26.

[2] Arikunto, S. 2010. Prosedur Penelitian Suatu Pendekatan Praktik. Jakarta:

[3] Rineka Cipta.

[4] Bangun, Wilson. 2012. Manajemen Sumber Daya Manusia. Jakarta: Erlangga.

[5] Bary, 2012. Human Resourse Manajemen, Elex Media Komputindo, Jakarta.

[6] Dadang. 2013. E-Busiess \& E-Commerce.Yogyakarta:

Andi.

[7] Dahlius, Apri. 2014. Pengaruh Fasilitas Kerja terhadap Kepuasan Kerja karyawan

[8] pada PT.Bank RiauKepri cabang Teluk Kuantan
Kabupaten Kuantan Singingi : Jurnal berkala ilmiah, 2014.

[9] Elisabeth, Pingkan Ratag. 2016. Pengaruh Pelatihan, Fasilitas Kerja, dan

[10] Kompensasi terhadap Kepuasan Kerja Karyawan pada PT. United Tractor cabang Manado : Jurnal berkala ilmiah efisiensi vol 16 no 3, 2016.

[11] Handoko, 2011. Manajemen Personalia dan Sumber Daya Manusia. Yogyakarta ;

a. BPFE.

[12] Mangkunegara, 2011. Manajemen Sumber Daya Manusia Perusahaan. Bandung ;

a. PT. Remaja Rosdakarya.

[13] Mangkunegara, 2015. Manajemensumber daya . bandung: remaja rosdakarya.

[14] Moenir. 2013. pendekatan manusia danorganisasi terhadap pembinaan

[15] kepegawaianjakarta: gunungagung.

[16] Nirwana. 2014. Pemasaran Jasa, Penerbit Alta, Jakarta.

[17] Priansa. 2014. Perencanaan \& Pengembangan SDM. Bandung: Alfabeta.

[18] Ranupandjojo dan Saud. Husnan. 2010. Manajemen Personalia. BPFE. Yogyakarta.

[19] Rivai. 2011. Manajemen Sumber Daya Manusia untuk Perusahaan dari Teori

a. ke Praktek. Jakarta ; PT. Raja Grafindo Persada. 